\title{
Effects of Microbial Fertilizer on the Growth, Physiology, and Chlorophyll Fluorescence Response of Spinach Seedlings
}

beibei zhang ( $\sim$ zbb83101@126.com)

Baoji University of Arts and Sciences

Qi Jing

Baoji University of Arts and Sciences

Hui Zhang

Baoji University of Arts and Sciences

Jiaxuan Wang

Baoji University of Arts and Sciences

Yang Yang

Baoji University of Arts and Sciences

\section{Research article}

Keywords: Bacillus, Growth, Physiological characters, Chlorophyll fluorescence

Posted Date: June 4th, 2020

DOI: https://doi.org/10.21203/rs.3.rs-31406/v1

License: (c) (i) This work is licensed under a Creative Commons Attribution 4.0 International License. Read Full License 


\section{Abstract}

We investigated the effects of different types of bacillus on the growth, physiological characteristics, and chlorophyll fluorescence of spinach seedlings in the soil environment of a Qinxi demonstration garden in Taibai County. Five different fertilization treatments were conducted in the growing room: no fertilizer (CK), addition of Bacillus subtilis (Bs, T1), addition of $B s$ and Bacillus mucilaginosus (Bm) (T2), addition of Bs and Bacillus amyloliquefaciens (Ba) (T3), and addition of $B s$ and $B a$ (T4). There were significant differences in the plant height (PH), leaf length (LL), and leaf weight (LW) of the spinach seedlings $(F=54.37,13.30$, and 46.03 , respectively; $P<0.01)$. The growth and physiological characteristics of the spinach seedlings attained a maximum under the $B s$ and $B m$ treatments. There were differences in the activities of the PSII reaction centers between the five treatments. Under the $B s$ and $B m$ treatments, the $A B S / R C, T R_{0} / R C$, and $E T_{0} / R C$ increased significantly, while the $\mathrm{DI}_{0} / \mathrm{RC}$ decreased. The OJIP curve increased under different types of fertilization, and the growth trends under the $B s$ and $B m$ treatments were the largest. The leaf light response curve (LC) increased significantly under the $B s$ and $B m$ treatments. The plant growth characteristics (LL, LW, $\mathrm{PH}$ ) were positively correlated with the J-I-P test chlorophyll fluorescence parameters $\left(\mathrm{PI}_{\mathrm{ABS}}, \varphi \mathrm{P}_{0}, \varphi \mathrm{E}_{0}, \Psi_{0}, \mathrm{TR}_{0} / \mathrm{RC}\right.$, and $\left.\mathrm{ET}_{0} / \mathrm{RC}\right)$, and negatively correlated with $\varphi \mathrm{D}_{0}$ and $\mathrm{DI}_{0} / \mathrm{RC}$. The leaf physiological characteristics (SP, SC, Chla, Chlb, Chla+b, Chla/b, and WP) were positively correlated with the J-I-P test chlorophyll fluorescence parameters $\left(\mathrm{PI}_{\mathrm{ABS}}, \varphi \mathrm{P}_{0}, \varphi \mathrm{E}_{0}, \Psi_{0}, \mathrm{ABS} / \mathrm{RC}, \mathrm{TR}_{0} / \mathrm{RC}\right.$, and $\left.\mathrm{ET}_{0} / \mathrm{RC}\right)$, and negatively correlated with $\varphi \mathrm{D}_{0}$ and $\mathrm{DI}_{0} / \mathrm{RC}$. The leaf MDA was significantly positively correlated with $\varphi D_{0}$ and $D_{0} / R C$, and positively correlated with other J-I-P test chlorophyll fluorescence parameters. The $B s$ and $B m$ treatments promoted the growth of the spinach seedlings and improved the adaptability of the crops to soil by enhancing the effective phosphorus utilization rate.

\section{Introduction}

In recent years, with the rapid development of the vegetable industry in China, fertilization has become the main strategy for improving yields. With the cultivation of vegetables gradually increasing over the years, the excessive application of chemical fertilizers has led to progressively serious soil problems. Therefore, microbial fertilizers have gradually replaced chemical fertilizers as a good method to improve soil quality, while increasing vegetable yields. Microbial fertilizers are also referred to as bacterial fertilizer, biological fertilizer, and microbial inoculant (Shen et al., 2011), which contain beneficial microorganisms that provide fertilization for crops through their activities. The metabolic activities of microorganisms can improve soil fertility and crop quality, while increasing soil microorganism populations, reduce plant diseases, and enhance plant root activities. Cao et al. (2011) and Manjurul et al. (2012) showed that biological fertilizers rich in Trichoderma could increase mustard and tomato yields, while reducing the need for the excessive use of $\mathrm{N}, \mathrm{P}$, and $\mathrm{K}$ in crop cultivation.

Bacillus is a type of growth-promoting bacteria that can produce phytase at the rhizosphere of plants. It has strong resistance to ultraviolet light, high salt, high acid, high heat, and radiation, with the capacity to inhibit bacteria, prevent disease, and increase production (Cavalcanti et al., 2018; Guo et al., 2009). Bacillus subtilis can improve the stress resistance of plants (Pliego and Ramos., 2010) and the availability of nitrogen and phosphorus in soil (Idriss and Borriss., 2002). Bacillus mucilaginosus converts the unusable phosphorus in soil to available phosphorus for plants. Simultaneously, $B m$ can secrete substances that promote plant growth and development, such as growth hormones, gibberellin, and more (Liu et al., 2016; Zhao et al., 2009). Bacillus amyloliquefaciens has a certain antagonistic effect on bacterial diseases. Arrebola et al. (2009) showed that Bacillus amylolyticus PPCB004 could inhibit the mycelial extensions of Penicillium fungi.

Photosynthesis is a process through which plants convert captured light energy into biochemical energy. Chlorophyll fluorescence can reflect the processes of light reactions in plants (Goltsev et al., 2009). The chlorophyll fluorescence technique can accurately analyze the distribution of light energy without harming the leaves of plants, and is considered a rapid and nondestructive probe for measuring leaf photosynthesis. Through the analyses of chlorophyll fluorescence parameters, a further elucidation of the light energy absorption, utilization, transfer, and dissipation of plant chloroplast PSI and PSII processes can be obtained (Li et al., 2005). 
The chlorophyll fluorescence technique has also been widely investigated for the detection of physiological changes in plants that are caused by bacterial and fungal infections. Cen et al. (2016) and Chen et al. (2012) revealed that there was a good correlation between chlorophyll fluorescence parameters and the degree of Verticillium wilt infection in cotton leaves. Tung et al. (2013) quantitatively analyzed the degree of infected tobacco (infected, unmanifested infection, healthy) according to Fv/Fm images, which indicated that chlorophyll fluorescence imaging technologies can detect the degree of infected tobacco. This revealed that the growth and physiological status of plants under different stresses can be monitored by chlorophyll fluorescence.

The purpose of this study was to explore the effects of different types of Bacillus on the growth, physiology, and chlorophyll fluorescence characteristics of spinach seedlings, and subsequently, to make reasonable plans for improving the quality and yields of spinach.

\section{Materials And Methods}

\subsection{Experimental materials}

These experiments employed the soil of a greenhouse at the Qinxi demonstration garden in Taibai County, Baoji County, Shaanxi Province as the test soil. The spinach (Spinacia oleracea L.) variety was big-leaf spinach, which belongs to the spinach genus Chenopodiaceae (annual herbaceous plant), and the seeds were provided by the demonstration garden. The Bacillus subtilis, Bacillus mucilaginosus, and Bacillus amyloliquefaciens selected the original strains produced by Lvlong Biotecnology Co., Ltd., which contained $>200$ million live bacteria per gram of fertilizer. The fertilizer components are all the Bacillus and its metabolites, and the rate of miscellaneous bacteria $<3 \%$.

\subsection{Growth conditions and experiment design}

The experiments were carried out in growth chambers at the College of Geography and Environment of Baoji University of Arts and Sciences under a $12 \mathrm{~h}$ day/night photoperiod at temperatures of $25 / 15^{\circ} \mathrm{C}$, respectively, a photosynthetically active radiation (PAR) of $300 \mu \mathrm{mol} /\left(\mathrm{m}^{2} \cdot \mathrm{s}\right)$, and humidity of $60 \%$. The spinach seeds were soaked in deionized water for $12 \mathrm{~h}$ and placed in a $4{ }^{\circ} \mathrm{C}$ refrigerator for $24 \mathrm{~h}$ to promote germination. The germinated seeds were placed on a seedling tray, covered with nutritious soil, and germinated in the dark in a $25{ }^{\circ} \mathrm{C}$ incubator. Following seven days of treatment, the seedlings were transferred to pot ( $\varnothing 25 \mathrm{~cm} \times 20 \mathrm{~cm}$ high) filled with greenhouse soil $18 \mathrm{~cm}$ deep, and 10 seedlings were planted in each pot. The soil nutrients were comprised of $33.35 \mathrm{~g} / \mathrm{kg}$ organic matter, $2.79 \mathrm{~g} / \mathrm{kg}$ total nitrogen, $1.51 \mathrm{~g} / \mathrm{kg}$ total phosphorus, and $10.75 \mathrm{mg} / \mathrm{kg}$ available phosphorus, and a pH of 5.2. For this experiment, $90 \mathrm{~kg} / \mathrm{hm}^{2}$ of phosphate fertilizer (potassium dihydrogen phosphate) was used as base fertilizer with microbial fertilizer $0.5 \mathrm{~kg} / \mathrm{hm}^{2}$. There were four treatments and three repeats (Table 1 ).

Table 1

combined application scheme of microbial fertilizer

\begin{tabular}{|ll|}
\hline Treatments & microbial fertilizer \\
\hline Ck & No added \\
\hline T1 & $B s$ \\
\hline T2 & $B s+B m$ \\
\hline T3 & $B s+B a$ \\
\hline T4 & $B m+B a$ \\
\hline Bs: Bacillus subtilis, Ba:Bacillus amyloliquefaciens, Bm: Bacillus mucilaginosus \\
\hline
\end{tabular}

\subsection{Measurement of growth characteristics}


For this experiment, all of the characteristics of the spinach leaves were measured $7 \mathrm{~d}$ after treatments. The plant height (PH), leaf length (LL) and leaf weight (LW) were measured with a scale.

\subsection{Measurement of physiological characteristics}

The leaf soluble protein (SP), soluble carbohydrate (SC), and water potential (WP) were closely related to plant metabolism. Chlorophyll (Chl) is an important substance in plant photosynthesis, and malondialdehyde (MDA) can reflect the degree of membrane lipid peroxidation. Within seven to 10 days of fertilization, the SP was determined by the Coomassie brilliant blue (CBB) method at $595 \mathrm{~nm}$ using a DR6000 spectrophotometer (Bradford, 1976), whereas the SC was determined using an anthrone method at $620 \mathrm{~nm}$ (Jermyn, 1975). The leaf Chla and Chlb concentrations were determined by Litchtenthaler (1983) at 645 and $663 \mathrm{~nm}$, whereas the leaf MDA was determined by the thiobarbituric acid method (Draper et al., 1993). The WP ( $\psi$ ) of the leaves was measured by dew point potentiometer (WP4, Decagon Devices, Pullman, USA).

\subsection{Chlorophyll fluorescence measurements}

Prior to the fluorometer measurements, the leaves were dark-adapted for $20 \mathrm{~min}$ and then measured using a FluorPen FP 100 Max hand fluorescence meter (Photon Systems Instruments, Brno,Czech Republic), and calculated according to the JIPtest algorithm proposed by Strasser et al. (2010) (Table 2). 


\begin{tabular}{|c|c|}
\hline $\begin{array}{l}\text { Parameters and } \\
\text { Formula }\end{array}$ & Meaning \\
\hline $\mathrm{F}_{0}$ & minimum fluorescence \\
\hline $\mathrm{Fm}$ & maximum fluorescence \\
\hline $\mathrm{F}_{J}$ & Ft at Time $2 \mathrm{~ms}$ \\
\hline $\mathrm{F}_{1}$ & Ft at Time $30 \mathrm{~ms}$ \\
\hline$F_{t}$ & The relative fluorescence intensity at Time $t$ \\
\hline $\mathrm{Fv}=\mathrm{Fm}-\mathrm{F}_{0}$ & variable fluorescence \\
\hline $\mathrm{nFv}=\mathrm{Fv} / \mathrm{F}_{0}$ & variable to initial fluorescence ratio \\
\hline$V_{1}=\left(F_{J}-F_{0}\right) /\left(F m-F_{0}\right)$ & Relative variable fluorescence at the l-step \\
\hline$V_{J}=\left(F_{J}-F_{0}\right) /\left(F m-F_{0}\right)$ & Relative variable fluorescence at the J-step \\
\hline$M_{0}$ & Approximated initial slope (in $m s-1$ ) of the fluorescence transient $V=f(t)$ \\
\hline $\mathrm{PI}_{\mathrm{ABS}}$ & $\begin{array}{l}\text { Performance index (potential) for energy conservation from exciton to the reduction of } \\
\text { intersystem electron acceptors }\end{array}$ \\
\hline $\mathrm{ABS} / \mathrm{RC}$ & Absorption flux (of antenna Chls) per RC \\
\hline $\mathrm{TR}_{0} / \mathrm{RC}=\mathrm{M}_{0}\left(1 / \mathrm{V}_{\mathrm{J}}\right)$ & Trapping flux (leading to QAreduction) per RC \\
\hline $\mathrm{ET}_{0} / \mathrm{RC}=\mathrm{M}_{0}\left(1 / \mathrm{V}_{\mathrm{J}}\right) \Psi_{\mathrm{O}}$ & Electron transport flux (further than $\mathrm{QA}^{-}$) per $\mathrm{RC}$ \\
\hline $\begin{array}{l}\mathrm{DI}_{0} / \mathrm{RC}=(\mathrm{ABS} / \mathrm{RC}- \\
\left.\mathrm{TR}_{0} / \mathrm{RC}\right)\end{array}$ & Dissipated energy flux per RC (at $t=0)$ \\
\hline$\varphi P_{0}=1-F_{0} / F m$ & Maximum quantum yield of primary photochemistry $($ at $t=0)$ \\
\hline $\begin{array}{l}\varphi E_{0}=\left(1-F_{0} / F m\right)(1- \\
\left.V_{J}\right)\end{array}$ & Quantum yield of electron transport (at $\mathrm{t}=0$ ) \\
\hline$\Psi_{0}=\mathrm{ET}_{0} / \mathrm{Tr}_{0}=1-\mathrm{V}_{\mathrm{J}}$ & $\begin{array}{l}\text { The probability that a trapped exciton moved an electron in electron transport chain further than } \\
\mathrm{QA}^{-}(\mathrm{t}=0)\end{array}$ \\
\hline$\varphi \mathrm{D}_{0}=\mathrm{F}_{0} / \mathrm{Fm}$ & Quantum yield $($ at $t=0)$ of energy dissipation \\
\hline
\end{tabular}

To compare the OJIP curve with the normalized PF transient curve between OJ and OK, the following formula was used:

$\mathrm{Vt}=\left(\mathrm{F}_{\mathrm{t}}-\mathrm{F}_{0}\right) /\left(\mathrm{Fm}-\mathrm{F}_{0}\right)(1)$

$\Delta \mathrm{Vt}=\mathrm{Vt}^{\mathrm{TR}}-\mathrm{Vt} \mathrm{t}^{\mathrm{CK}}(2)$

$W_{O J}=\left(F_{t}-F_{0}\right) /\left(F_{j}-F_{0}\right)(3)$

$\Delta \mathrm{W}_{\mathrm{OJ}}=\mathrm{W}_{\mathrm{OJ}}{ }^{\mathrm{TR}}-\mathrm{W}_{\mathrm{OJ}}{ }^{\mathrm{CK}}(4)$

$\mathrm{W}_{\mathrm{OK}}=\left(\mathrm{F}_{\mathrm{t}}-\mathrm{F}_{0}\right) /\left(\mathrm{F}_{\mathrm{K}}-\mathrm{F}_{0}\right)(5)$ 
$\Delta \mathrm{W}_{\mathrm{OK}}=\mathrm{W}_{\mathrm{OK}}^{\mathrm{TR}}-\mathrm{W}_{\mathrm{OK}}^{\mathrm{CK}}(6)$

The leaf light-response curve (LC) measurement, based on pulse modulated fluorometry (PAM) was designed using seven photosynthetic photon flux densities (PPFD) $\left(10,20 \rrbracket 50 \rrbracket 100 \rrbracket 300 \otimes 500\right.$, and $\left.1000 \mu \mathrm{mol} /\left(\mathrm{m}^{2} \cdot \mathrm{s}\right)\right)$ to acquire chlorophyll fluorescence parameter changing curves (Ft, QY) relating the rate of photosynthesis.

\subsection{Statistical analysis of data}

All collected data were subjected to one-way ANOVA analysis using SPSS (SPSS software version 22.0, Chicago, Illinois, USA). Differences between means were compared by Tukey's HSD test at $\mathrm{P}<0.05$. The correlations between parameters were determined using Pearson's simple correlation test function in SPSS.

\section{Results}

\subsection{Effects of microbial fertilizer on growth and physiological characteristics of spinach seedlings}

There were significant differences in the plant height $(\mathrm{PH})$, leaf length (LL), leaf weight (LW), and other growth parameters of the spinach seedlings under the five different treatments $(F=54.37,13.30$, and 46.03 , respectively; $P<0.01)$, where the growth characteristics attained a maximum under the T2 treatment (Table 3). Except for Chla $+b$ and Chla/b, there were significant differences in the physiological characteristics of the leaves. Among them, the T2 treatment had the greatest impact on the physiological leaf responses. Compared with the $F$ value, the difference in soluble sugar (SC) was the highest $(F=118.35 ; P<$ 0.01 ). 
Table 3

Differences in microbial fertilizers on growth and physiological leaf characteristics of spinach

\begin{tabular}{|c|c|c|c|c|c|c|c|c|}
\hline \multirow[t]{2}{*}{ Treatments } & \multicolumn{8}{|c|}{ Growth characters } \\
\hline & \multicolumn{2}{|c|}{ Plant height $(\mathrm{PH}, \mathrm{cm})$} & \multicolumn{3}{|c|}{ Leaf length (LL, cm) } & \multicolumn{3}{|c|}{ Leaf weight (LW, g/10 plants) } \\
\hline CK & \multicolumn{2}{|c|}{$3.53 \pm 0.15 b$} & \multicolumn{3}{|c|}{$2.62 \pm 0.26 b$} & \multicolumn{3}{|c|}{$0.95 \pm 0.01 \mathrm{~d}$} \\
\hline T1 & \multicolumn{2}{|c|}{$5.23 \pm 0.09 a$} & \multicolumn{3}{|c|}{$4.08 \pm 0.05 a$} & \multicolumn{3}{|c|}{$2.08 \pm 0.02 b$} \\
\hline T2 & \multicolumn{2}{|c|}{$5.27 \pm 0.09 a$} & \multicolumn{3}{|c|}{$4.15 \pm 0.09 a$} & \multicolumn{3}{|c|}{$2.69 \pm 0.02 \mathrm{a}$} \\
\hline T3 & \multicolumn{2}{|c|}{$5.05 \pm 0.03 \mathrm{a}$} & \multicolumn{3}{|c|}{$3.73 \pm 0.18 a$} & \multicolumn{3}{|c|}{$1.47 \pm 0.02 c$} \\
\hline T4 & \multicolumn{2}{|c|}{$5.07 \pm 0.03 a$} & \multicolumn{3}{|c|}{$3.89 \pm 0.19 a$} & \multicolumn{3}{|c|}{$1.74 \pm 0.01 c$} \\
\hline $\mathrm{F}$ value & \multicolumn{2}{|l|}{$54.37 * \star$} & \multicolumn{2}{|c|}{$13.30 * \star$} & & \multicolumn{3}{|c|}{$46.03 \star \star$} \\
\hline \multirow[t]{3}{*}{ Treatments } & \multicolumn{8}{|c|}{ Physiological leaf characteristics } \\
\hline & $\mathrm{SP}$ & SC & MDA & Chl a & Chl b & $\mathrm{Chl} \mathrm{a}+\mathrm{b}$ & $\mathrm{Chl} \mathrm{a/b}$ & $\mathrm{WP}(\Psi, \mathrm{Mpa})$ \\
\hline & $(\mathrm{mg} / \mathrm{gFW})$ & $(\mathrm{mg} / \mathrm{gFW})$ & $(\mathrm{mg} / \mathrm{gFW})$ & $(\mathrm{mg} / \mathrm{gFW})$ & $(\mathrm{mg} / \mathrm{gFW})$ & $(\mathrm{mg} / \mathrm{gFW})$ & $(\mathrm{mg} / \mathrm{gFW})$ & \\
\hline CK & $\begin{array}{l}1.83 \pm \\
0.26 c\end{array}$ & $\begin{array}{l}0.73 \pm \\
0.05 \mathrm{~d}\end{array}$ & $\begin{array}{l}5.49 \pm \\
0.51 \mathrm{a}\end{array}$ & $\begin{array}{l}1.16 \pm \\
0.03 e\end{array}$ & $\begin{array}{l}0.36 \pm \\
0.03 c\end{array}$ & $\begin{array}{l}1.52 \pm \\
0.03 e\end{array}$ & $\begin{array}{l}3.25 \pm \\
0.30 b\end{array}$ & $\begin{array}{l}-6.57 \pm \\
0.25 d\end{array}$ \\
\hline T1 & $\begin{array}{l}3.31 \pm \\
0.20 \mathrm{~b}\end{array}$ & $\begin{array}{l}2.26 \pm \\
0.06 \mathrm{~b}\end{array}$ & $\begin{array}{l}1.80 \pm \\
0.13 \mathrm{~b}\end{array}$ & $\begin{array}{l}2.73 \pm \\
0.22 \mathrm{~b}\end{array}$ & $\begin{array}{l}0.58 \pm \\
0.06 a b\end{array}$ & $\begin{array}{l}3.30 \pm \\
0.15 \mathrm{~b}\end{array}$ & $\begin{array}{l}4.91 \pm \\
0.83 a\end{array}$ & $\begin{array}{l}-4.23 \pm \\
0.12 b\end{array}$ \\
\hline T2 & $\begin{array}{l}4.14 \pm \\
0.04 a\end{array}$ & $\begin{array}{l}3.59 \pm \\
0.13 a\end{array}$ & $\begin{array}{l}1.25 \pm \\
0.14 \mathrm{~b}\end{array}$ & $\begin{array}{l}3.23 \pm \\
0.04 a\end{array}$ & $\begin{array}{l}0.60 \pm \\
0.03 \mathrm{~b}\end{array}$ & $\begin{array}{l}3.83 \pm \\
0.07 a\end{array}$ & $\begin{array}{l}5.36 \pm \\
0.25 a\end{array}$ & $\begin{array}{l}-2.79 \pm \\
0.22 a\end{array}$ \\
\hline T3 & $\begin{array}{l}2.37 \pm \\
0.08 \mathrm{c}\end{array}$ & $\begin{array}{l}1.59 \pm \\
0.11 \mathrm{~b}\end{array}$ & $\begin{array}{l}4.82 \pm \\
0.31 \mathrm{a}\end{array}$ & $\begin{array}{l}1.70 \pm \\
0.07 \mathrm{~d}\end{array}$ & $\begin{array}{l}0.40 \pm \\
0.01 \mathrm{c}\end{array}$ & $\begin{array}{l}2.11 \pm \\
0.07 \mathrm{~d}\end{array}$ & $\begin{array}{l}4.21 \pm \\
0.09 \mathrm{ab}\end{array}$ & $\begin{array}{l}-5.53 \pm \\
0.26 c\end{array}$ \\
\hline T4 & $\begin{array}{l}3.28 \pm \\
0.22 \mathrm{~b}\end{array}$ & $\begin{array}{l}2.23 \pm \\
0.11 \mathrm{c}\end{array}$ & $\begin{array}{l}2.09 \pm \\
0.15 b\end{array}$ & $\begin{array}{l}2.29 \pm \\
0.11 \mathrm{c}\end{array}$ & $\begin{array}{l}0.47 \pm \\
0.02 \mathrm{bc}\end{array}$ & $\begin{array}{l}2.75 \pm \\
0.09 c\end{array}$ & $\begin{array}{l}4.91 \pm \\
0.43 a\end{array}$ & $\begin{array}{l}-4.79 \pm \\
0.12 b\end{array}$ \\
\hline$F$ value & $24.48 * \star$ & $118.35^{\star \star}$ & $44.95^{\star \star}$ & $50.63^{\star \star}$ & $8.80 \star \star$ & 0.12 & 3.34 & $48.72 \star \star$ \\
\hline
\end{tabular}

\subsection{Differential analysis of chlorophyll fluorescence parameters of spinach seedlings by adding microbial fertilizer}

According to the values of the basic fluorescence parameters (Table 4), the $F_{0}$ value of the $T 2$ treatment was the highest, which was $41.29 \%$ higher than that of CK. Further, the Fm value of the T2 treatment was 17751 later than that of CK, and there was a significant difference in $F_{V}$ value under the five treatments. The relative variable fluorescence value $\left(V_{1}\right)$ at 30 ms was highest under the $\mathrm{T} 2$ treatment. In terms of the $\mathrm{nF}_{\mathrm{V}}$ value, the T2 treatment remained the largest. Compared with the $\mathrm{F}$ value, the difference in the $F_{0}$ was the largest $(F=112.57 ; P<0.01)$. 
Table 4

difference analysis of chlorophyll fluorescence parameters of microbial fertilizer added to five different treatments

\section{Treatments Leaf chlrophyll fluorescence intensity (relative unit)}

\begin{tabular}{|c|c|c|c|c|c|c|}
\hline & $\mathrm{F}_{0}$ & $\mathrm{Fm}$ & $\mathrm{Fv}$ & $\mathrm{V}_{\mathrm{J}}$ & $V_{1}$ & $\mathrm{Fv} / \mathrm{F}_{0}(\mathrm{nFv})$ \\
\hline CK & $\begin{array}{l}7087 \pm \\
188 b\end{array}$ & $28967 \pm 1440 c$ & $21880 \pm 1628 c$ & $0.46 \pm 0.06 a$ & $\begin{array}{l}0.76 \pm \\
0.01 \mathrm{bc}\end{array}$ & $\begin{array}{l}4.07 \pm \\
0.03 b\end{array}$ \\
\hline $\mathrm{T} 1$ & $\begin{array}{l}9233 \pm \\
568 a b\end{array}$ & $43142 \pm 1342 a b$ & $33909 \pm 1286 a b$ & $0.54 \pm 0.03 a b$ & $\begin{array}{l}0.82 \pm \\
0.01 a b\end{array}$ & $\begin{array}{l}3.67 \pm \\
0.11 \mathrm{a}\end{array}$ \\
\hline $\mathrm{T} 2$ & $\begin{array}{l}10013 \pm \\
10 a b\end{array}$ & $46718 \pm 1126 a$ & $36705 \pm 1136 a$ & $0.47 \pm 0.00 a b$ & $\begin{array}{l}0.85 \pm \\
0.02 a\end{array}$ & $\begin{array}{l}4.08 \pm \\
0.11 a\end{array}$ \\
\hline T3 & $\begin{array}{l}9071 \pm \\
108 a b\end{array}$ & $31861 \pm 131 b c$ & $22790 \pm 23 b c$ & $0.47 \pm 0.01 b$ & $\begin{array}{l}0.76 \pm \\
0.00 c\end{array}$ & $\begin{array}{l}2.51 \pm \\
0.41 \mathrm{~b}\end{array}$ \\
\hline $\mathrm{T} 4$ & $9786 \pm 38 a$ & $41549 \pm 1544 a b$ & $31763 \pm 1506 a b c$ & $0.46 \pm 0.00 \mathrm{ab}$ & $\begin{array}{l}0.77 \pm \\
0.01 \mathrm{bc}\end{array}$ & $\begin{array}{l}3.25 \pm \\
0.24 a\end{array}$ \\
\hline F value & $112.57 * \star$ & $31.13^{* *}$ & $24.01 * *$ & 2.48 & $3.85^{\star}$ & $8.3^{\star \star}$ \\
\hline
\end{tabular}

Treatments J-I-P test parameters (relative unit)

\begin{tabular}{|c|c|c|c|c|c|c|}
\hline & $\mathrm{M}_{0}$ & $\mathrm{PI}_{\mathrm{ABS}}$ & $\mathrm{ABS} / \mathrm{RC}$ & $\mathrm{TR}_{0} / \mathrm{RC}$ & $\mathrm{ET}_{0} / \mathrm{RC}$ & $\mathrm{DI}_{0} / \mathrm{RC}$ \\
\hline CK & $\begin{array}{l}0.91 \pm \\
0.03 \mathrm{ab}\end{array}$ & $\begin{array}{l}0.38 \pm \\
0.29 c\end{array}$ & $2.20 \pm 0.08 a b$ & $1.37 \pm 0.06 a b$ & $0.46 \pm 0.04 b$ & $0.82 \pm 0.06 a$ \\
\hline T1 & $\begin{array}{l}1.08 \pm \\
0.07 a\end{array}$ & $\begin{array}{l}1.24 \pm \\
0.21 \mathrm{ab}\end{array}$ & $2.57 \pm 0.03 a$ & $2.02 \pm 0.01 \mathrm{ab}$ & $0.94 \pm 0.03 a$ & $0.55 \pm 0.02 c$ \\
\hline T2 & $\begin{array}{l}1.00 \pm \\
0.02 a\end{array}$ & $\begin{array}{l}1.70 \pm \\
0.23 a\end{array}$ & $2.59 \pm 0.03 a$ & $2.08 \pm 0.04 a$ & $1.07 \pm 0.01 a$ & $0.51 \pm 0.01 b$ \\
\hline T3 & $\begin{array}{l}0.67 \pm \\
0.01 a b\end{array}$ & $\begin{array}{l}1.41 \pm \\
0.01 \mathrm{bc}\end{array}$ & $2.01 \pm 0.00 b$ & $1.43 \pm 0.02 b$ & $0.76 \pm 0.01 \mathrm{ab}$ & $0.57 \pm 0.01 a b$ \\
\hline T4 & $\begin{array}{l}0.83 \pm \\
001 b\end{array}$ & $\begin{array}{l}1.61 \pm \\
0.03 \mathrm{bc}\end{array}$ & $2.35 \pm 0.08 a b$ & $1.80 \pm 0.01 \mathrm{ab}$ & $0.96 \pm 0.01 \mathrm{ab}$ & $0.55 \pm 0.00 \mathrm{bc}$ \\
\hline F value & $7.66^{\star \star}$ & $4.09 *$ & 2.88 & $3.97 *$ & 2.04 & $8.16^{\star *}$ \\
\hline
\end{tabular}

Treatments Yield and efficiency

\begin{tabular}{lllll} 
& $\varphi \mathrm{P}_{0}(\mathrm{Fv} / \mathrm{Fm})$ & $\varphi \mathrm{E}_{0}$ & $\Psi_{0}$ & $\varphi \mathrm{D}_{0}$ \\
\hline CK & $0.62 \pm 0.01 \mathrm{c}$ & $0.22 \pm 0.01 \mathrm{ab}$ & $0.34 \pm 0.01 \mathrm{ab}$ & $0.37 \pm 0.01 \mathrm{ab}$ \\
\hline T1 & $0.78 \pm 0.01 \mathrm{ab}$ & $0.37 \pm 0.01 \mathrm{a}$ & $0.47 \pm 0.01 \mathrm{a}$ & $0.21 \pm 0.00 \mathrm{c}$ \\
\hline T2 & $0.80 \pm 0.00 \mathrm{a}$ & $0.41 \pm 0.06 \mathrm{~b}$ & $0.52 \pm 0.05 \mathrm{a}$ & $0.19 \pm 0.00 \mathrm{bc}$ \\
\hline T3 & $0.72 \pm 0.0 \mathrm{bc}$ & $0.38 \pm 0.03 \mathrm{ab}$ & $0.53 \pm 0.02 \mathrm{~b}$ & $0.29 \pm 0.03 \mathrm{a}$ \\
\hline T4 & $0.76 \pm 0.01 \mathrm{ab}$ & $0.41 \pm 0.00 \mathrm{ab}$ & $0.54 \pm 0.00 \mathrm{ab}$ & $0.24 \pm 0.01 \mathrm{bc}$ \\
\hline F value & $6.03^{\star *}$ & 2.48 & 2.71 & $6.02^{\star *}$
\end{tabular}

The values presented in each column of table have a mean \pm standard deviation. The last part of table refers to the $F$ value. * $\mathrm{P}<0.05, * \star \mathrm{P}<0.01$.

There were significant differences between the $\mathrm{M}_{0}$ and $\mathrm{Pl}_{\mathrm{ABS}}$ values under the five different treatments $(\mathrm{F}=7.66$ and 4.09 , respectively; $\mathrm{P}<0.05)$. The $\mathrm{T} 2$ treatment had the greatest effect on the specific activity of each reaction center $(\mathrm{RC})$, and there was a significant difference between the $\mathrm{TR}_{0} / \mathrm{RC}$ and $\mathrm{DI}_{0} / \mathrm{RC}$. However, there was no significant difference in the $A B S / R C$ and 
$\mathrm{ET}_{0} / \mathrm{RC}$ between the treatments. The quantum yield $\left(\varphi \mathrm{P}_{0}\right)$, efficiency $\left(\varphi \mathrm{E}_{0}\right)$, and $\psi_{0}$ values were highest under the T2 treatment, and with the exception of $\Psi_{0}$, there were significant differences $(P<0.01)$. On the contrary, the value of $\varphi D_{0}$ was lowest under the T2 treatment.

\subsection{Transient analysis of prompt fluorescence OJIP of spinach seedlings by adding microbial fertilizer}

By measuring the transient curve of OJIP as shown in Fig. 1, the OJIP curves of the five treatments were similar to those reported by Strasser et al. (2004). As can be seen from Fig. 1(A), compared with CK, the fluorescence trend of the other treatments gradually increased, among which the fluorescence value of the T2 treatment was the largest, which signified that it had a greater effect on the photosynthetic chemical rate of the leaves. As shown in Fig. 1(B), the difference of relative variable fluorescence $(\mathrm{Vt})$ at point $\mathrm{J}(2 \mathrm{~ms})$ was the largest. This is better illustrated in Fig. 1(C) $\Delta \mathrm{Vt}$. Over time the difference between the treatments increased initially and then decreased, and the difference in the initial slope of the 0-J stage curve was maximized. Oukarroum et al. (2007) regarded the double normalization of the OJIP transient between the peak value of 0.05 to $2 \mathrm{~ms}$, and the difference of double normalization between the treatment and the control group as the K-band. It can be seen from Figs. 1D,E that there is an obvious positive $\mathrm{K}$ band under the $\mathrm{T} 1$ and $\mathrm{T} 2$ treatments, and a negative growth trend under the T3 and T4 treatments. The transient double normalization of OJIP between Fo and $F_{K}$ and the difference of double normalization between the treatments and the control group were regarded as the $L$ band (Oukarroum et al., 2007). As shown in Figure. $1 F, G$ the $W_{O K}$ value of the $T 2$ treatment was higher, and there was a significantly higher positive $L$ band.

\subsection{Analysis of the difference of the Light response Curve $(L C)$ of the spinach seedlings by adding microbial fertilizer}

Compared with the five treatments, the quantum yield (QY) of leaves under the T2 treatment attained a maximum at $20 \mu \mathrm{mol} /\left(\mathrm{m}^{2} \cdot \mathrm{s}\right)$ PPFD, which indicated that the light compensation point (LCP) was $\sim 20 \mu \mathrm{mol} /\left(\mathrm{m}^{2} \cdot \mathrm{s}\right)$ PPFD. The maximum value of the other treatments was before $10 \mu \mathrm{mol} /\left(\mathrm{m}^{2} \cdot \mathrm{s}\right)$ PPFD, indicating that the LCP was earlier than $10 \mu \mathrm{mol} /\left(\mathrm{m}^{2} \cdot \mathrm{s}\right)$ PPFD.

\subsection{Correlations between growth, physiological characteristics and leaf chlorophyll}

\section{fluorescence}

Through correlation analyses the characteristics of the growth, physiology, and chlorophyll fluorescence of leaves were quantified. Plant growth characteristics $(\mathrm{LL}, \mathrm{LW}, \mathrm{PH})$ were positively correlated with chlorophyll fluorescence parameters $\left(\mathrm{PI} \mathrm{ABS}_{\mathrm{B}}\right.$ $\left.\varphi P_{0}, \varphi E_{0}, \Psi_{0}, T_{0} / R C, E T_{0} / R C\right)$ using a J-I-P test, and negatively correlated with $\varphi D_{0}$ and $\mathrm{DI}_{0} / R C$. The physiological characteristics of the leaves (SP, SC, Chla, Chlb, Chla $+b$, Chla/b, and WP) were positively correlated with PIABS, $\varphi P_{0}, \varphi E_{0}, \Psi_{0}$, $A B S / R C, T R_{0} / R C$ and $E T_{0} / R C$, and negatively correlated with $\varphi D_{0}$ and $D I_{0} / R C$. The leaf $M D A$ was significantly positively correlated with $\varphi \mathrm{D}_{0}$ and $\mathrm{DI}_{0} / \mathrm{RC}$, and positively correlated with other chlorophyll fluorescence parameters tested by J-I-P (Table 5). 
Table 5

Correlations between leaf physiological characteristics and chlorophyll fluorescence parameters.

\begin{tabular}{|c|c|c|c|c|c|c|c|c|c|c|c|}
\hline Index & LW & LL & $\mathrm{PH}$ & SP & SC & Chla & Chlb & $\begin{array}{l}\text { Chla + } \\
\text { b }\end{array}$ & Chla/b & MDA & WP \\
\hline $\mathrm{PI}_{\mathrm{ABS}}$ & $0.75^{\star \star}$ & $0.84^{\star \star}$ & $0.92^{\star \star}$ & $0.76^{\star \star}$ & $0.81^{\star *}$ & $0.73^{\star \star}$ & $0.55^{\star}$ & $0.73^{\star \star}$ & $0.68^{\star \star}$ & -0.71 ** & $0.75^{\star \star}$ \\
\hline$\varphi P_{0}$ & $0.90 \star \star$ & $0.89 \star \star$ & 0.91 ** & $0.89 \star \star$ & 0.90 ** & $0.93^{\star \star}$ & $0.80^{\star \star}$ & $0.93^{\star \star}$ & $0.74^{\star \star}$ & -0.91 ** & $0.90^{\star \star}$ \\
\hline$\varphi \mathrm{E}_{0}$ & $0.58 *$ & $0.78^{\star \star}$ & $0.89 \star \star$ & $0.60 *$ & $0.65^{\star \star}$ & $0.56^{*}$ & 0.38 & $0.55^{\star}$ & $0.58^{\star}$ & $-0.55^{\star}$ & $0.58^{*}$ \\
\hline$\Psi_{0}$ & $0.74^{\star \star}$ & $0.86^{\star \star}$ & $0.95^{\star \star}$ & $0.75^{\star \star}$ & $0.79 * \star$ & $0.74^{\star \star}$ & $0.56^{\star}$ & $0.74^{\star \star}$ & $0.68^{\star \star}$ & $-0.72 \star \star$ & $0.74 * \star$ \\
\hline$\varphi D_{0}$ & $-0.90 * \star$ & $-0.89 * \star$ & $-0.91^{\star *}$ & -0.89 ** & -0.90 ** & -0.93 ** & $-0.80 * *$ & $-0.93^{\star \star}$ & -0.74 *夫 & $0.91^{\star \star}$ & -0.90 ** \\
\hline $\mathrm{ABS} / \mathrm{RC}$ & $0.77^{\star \star *}$ & 0.51 & 0.40 & $0.78^{\star \star}$ & $0.73^{\star \star}$ & $0.83^{\star \star}$ & 0.80 ** & $0.84^{\star \star}$ & $0.54^{\star}$ & $-0.85^{\star \star}$ & $0.78^{\star *}$ \\
\hline $\mathrm{TR}_{0} / \mathrm{RC}$ & $0.90 \star \star$ & $0.74^{\star \star}$ & $0.69 \star \star$ & $0.90 \star \star$ & $0.88^{\star *}$ & $0.94^{\star \star}$ & $0.86^{\star \star}$ & 0.96 ** & $0.68^{\star \star}$ & $-0.95^{\star \star}$ & $0.90 \star \star$ \\
\hline $\mathrm{ET}_{0} / \mathrm{RC}$ & $0.89 \star *$ & $0.88^{\star \star}$ & 0.90 ** & $0.91^{\star \star}$ & $0.92^{\star \star}$ & $0.91^{\star \star}$ & $0.76^{\star \star}$ & $0.92^{\star \star}$ & $0.75^{\star \star}$ & -0.91 ** & $0.90 * \star$ \\
\hline $\mathrm{DI}_{0} / \mathrm{RC}$ & $-0.80 \star \star$ & $-0.90 * \star$ & $-0.97 * \star$ & -0.78 ** & $-0.82^{\star *}$ & -0.80 ** & $-0.65^{\star \star}$ & $-0.81^{\star \star}$ & $-0.70 \star \star$ & $0.76^{\star \star}$ & $-0.79 * *$ \\
\hline
\end{tabular}

\section{Discussion}

\subsection{Physiological characteristics of growth and leaves}

Spinach is a type of Chenopodiaceae plant that is extensively planted in facility agriculture, which has strong environmental adaptability (Chen et al., 2016; Long et al., 2013). In terms of plant phenology and biological characteristics, plant growth, leaf chlorophyll content, and other physiological characteristics are critical influencing factors (Bennie et al., 2016). The results of Yan et al. (2017) revealed that the application of microbial fertilizer could effectively improve the plant height of pakchoi. In this study, the addition of microbial fertilizer effectively improved plant height, leaf length, and leaf weight, among which the growth status of plants with the addition of $B s$ and $B m$ was more dominant. This was similar to the results of Samia et al. (2014).

In this research, microbial fertilizer was found to significantly enhanced the physiological characteristics of spinach seedling leaves (SP, SC, Chla, Chlb, Chla + b, Chla/b, and WP). Wang et al. (2018) found that the application of microbial fertilizer could effectively increase the chlorophyll content of winter wheat at the overwintering, jointing, and booting stages. The application of phosphate fertilizer can promote the synthesis of chlorophyll in leaves (Li et al., 2002).

For this study, the chlorophyll content of leaves treated with $B s$ and $B m$ was at a higher level. It may be possible that the $B s$ and $B m$ convert ineffective phosphorus into available phosphorus in the soil, which improves the availability of phosphorus and enhances the ability of plants to absorb it, thus promoting the synthesis of ATP and NADPH in leaves. When plants are under stress, the MDA content is typically an important indicator of membrane lipid peroxidation, which reflects the harmful effects of stress on plant cells and tissues (Han et al., 2013). In this study, the concentration of MDA in leaves treated with microbial fertilizer decreased.

\subsection{Leaf chlorophyll fluorescence}

In this research, the values of $\mathrm{F}_{0}$ and $\mathrm{Fm}$ were enhanced, which indicated that the $B s$ and $B m$ promoted an increase in the size of leaf PSII antenna and a decrease in the non-radiative dissipation of chlorophyll in PSII antenna, thus increasing the capacity of leaves to capture light energy (Oukarroum et al., 2016). We observed higher Fv and Fv/ $\mathrm{F}_{0}(\mathrm{nFv}$ ) values under the $B s$ and $B m$

Page $10 / 15$ 
treatments, which signified an increase in the efficiency of supplying electrons to PSII RCS and the photosynthetic quantum conversion rate of PSII RCS. This translated to less energy being used for non-photochemical dissipation in the dark adaptation process (Spoustova et al., 2013).

In this experiment, the $A B S / R C$ values of the leaves increased, indicating that the $B s$ and $B m$ promoted the increased size of active RCS, which led to a higher number of active PSIl reaction centers and enhanced dark accumulation (Pooja et al., 2010). Under the action of the $B s$ and $B m$, the $\mathrm{TR}_{0} / \mathrm{RC}$ value increased, which reflected the higher electron capture rate of $\mathrm{RC}$, where more $\mathrm{QA}$ was converted to $\mathrm{QA}^{-}$. This resulted in an increase in the electron transfer energy $\left(\mathrm{ET}_{0} / \mathrm{RC}\right)$, thus reducing the energy dissipated by non-photochemical activities ( $\mathrm{DI}_{0} / \mathrm{RC}$ ) (Yiotis and Manetas, 2010; Tang et al., 2017).

The $\varphi P_{0}(\mathrm{Fv} / \mathrm{Fm})$ represents the maximum quantum yield of $\mathrm{PS} \otimes$, and the $\psi_{0}$ value reflects the electron transfer efficiency, from $\mathrm{QA}^{-}$to $\mathrm{QB}$, whereas $\varphi \mathrm{E}_{0}$ reflects the quantum yield of electron transport. The increase of $\varphi \mathrm{P}_{0}, \Psi_{0}$, and $\varphi \mathrm{E}_{0}$ indicated that the $B s$ and $B m$ promoted the redox reaction following QA, which resulted in an increase of the electron transfer rate between $\mathrm{QA}^{-}$and QB (Lebkuecher et al., 1999).

The change of the chlorophyll fluorescence curve is closely related to the physiological morphology of plants (Malaspina et al., 2015). Changes in the O-J segment are related to an increased number of inactive reaction centers, or the energy transfer from the LHCII to PSII reaction center (Tomar and Jajoo, 2013). The K and L bands reflect the connection between the S state of the PSIl oxygen evolution complex (OEC) and PSIl unit, as well as the energy connection between the PSIl units (DaBrowski et al., 2016; Paunov et al., 2018).

An increase in the $\mathrm{J}-\mathrm{I}$ segment can reflect a decrease in the relative number of active $\mathrm{PQ}$ molecules that is reduced by each active RC of PSII ((Paunov et al., 2018). Further, changes in the I-P segment are closely related to the pool of electron receptors (ferredoxin and NADPH) at the end of the PSI, signifying the kinetic flow rate to the electron receptors at the end of the PSI (Tsimilli Michael and Strasser, 2013). In this experiment, the OJIP transient curves of the spinach seedlings were affected by microbial fertilizer (Fig. 1).

Under the treatment of $B s$ and $B m$, the relative fluorescence intensity of chlorophyll in the 0-J segment exhibited a larger value, indicating that the population of active PSIl centers decreased, whereas the $\mathrm{QA}^{-}$accumulated massively. Figures $1 \mathrm{E}$ G show that there were obvious $\mathrm{K}$ bands and positive $\mathrm{L}$ bands under the $B s$ and $B m$ treatment, which indicated that the PSII had an inhibitory effect on the OEC. This resulted in a weakening of the connectivity between PSII and OEC and a decreased energy connection between the PSII units.

This may have been due to the variable light and ventilation that was present at different locations in the incubator, which may have led to PSI receptor side damage and chlorophyll protein denaturation in some plant leaves (Bertamini and Nedunchezhian, 2003). In addition, the fluorescence of $\mathrm{J}-\mathrm{I}$ and I-P segments remained large under the $B s$ and $B m$ treatment, which indicated that the relative number of $P Q$ decreased, while there was an increase in the pool of electron receptors (ferredoxin and NADPH) at the end of PSI, which led to a higher kinetic flow rate to the electron receptors at the end of PSI.

Combined with $\mathrm{PI}_{A B S}$, the higher $\mathrm{PI}_{A B S}$ values under the $B s$ and $B m$ treatment indicated increases in the density of active PSII centers, the efficacy of photoreactions, and efficiency of biochemical dark redox reactions, as well as the production and utilization of NADPH (Habib et al., 2016).

\section{Conclusions}

The main results of our study are as follows: Bacillus promoted the growth of spinach seedlings and improved the adaptability of crops to soil by improving the effective phosphorus utilization rate. Simultaneously, the chlorophyll content, soluble protein and other physiological characteristics, chlorophyll fluorescence, and PSII photochemical activity were improved to a certain extent.

Page $11 / 15$ 
The results revealed that under the $B s$ and $B m$ treatment, the growth conditions for the spinach seedlings were best, and the physiological index was higher. According to this study, it is suggested that inorganic fertilizer and Bacillus may be used together for soil fertilization in greenhouses. It can not only promote the utilization of mineral elements in the soil by plants to improve crop quality, but also prevent soil acidification caused by the excessive accumulation of mineral elements. Future research should endeavor to control the fertilization concentrations of microorganisms, so as to provide an improved theoretical basis for agricultural fertilization.

\section{Declarations}

\section{Acknowledgements}

This work was supported by the National Natural Science Foundation of China (NSFC, No. 41601016), Special Support Program for High-Level Personnel Recruitment (Youth Top-Talent) of Shaanxi province, National Natural Science Foundation of Shaanxi province (No. 2015JM4136), Key Project of Baoji University of Arts and Sciences (No. ZK2018025).

\section{Declarations}

The research passed the ethics approval and it was consent to participate. All the authors declare no competing interests and consent for publication. J. X. W. and Y.Y prepared the materials. B. B. Z designed the study. H. Z. did the data analysis. B. B. Z and Q. J wrote the main manuscript text. All authors discussed the results and commented on the paper.

\section{References}

1. Arrebola E, Jacobs R, Korstcn L. Iturin A is the principal inhibitor in the biocontrol activity of Bacillus amyloliquefaciens PPCB004 against postharvest fungal pathogens. J Appl Microbiol. 2010;108(2):386-95.

2. Bennie J, Davies TW, Cruse D, et.al. Ecological effects of artificial light at night on wild plants. J Ecol. 2016;104(3):61120.

3. Bertamini M, Nedunchezhian N. Photoinhibition of photosynthesis in mature and young leaves of grapevine (Vitis vinifera L.). Plant Sci. 2003;164(4):635-44.

4. Bradford MM. Arapid and sensitive method for the quantitation of microgram quantities of protein utilizing the principle of proteindye binding. Anal Biochem. 1976;72:248-54.

5. Cao EH, Hou XW, Li GY, et al. Effect of combination bacteria on soil physicochemical properties and soil microbial activity by pot tomato experiments. Ecology Environmental Sciences. 2011;20(5):875-80.

6. Cavalcanti VP, Araújo NAF, Schwan-Estrada KRF, et al. Athelia (Sclerotium) rolfsii in Allium sativum: Potential biocontrol agents and theireffects on plant metabolites. An Acad Bras Cienc. 2018;90(1):3949-62.

7. Cen HY, Weng HY, Yao JN, et al. Genomic Organization, Phylogenetic and Expression Analysis of the B-BOX Gene Family in Tomato. Front Plant Sci. 2016;10(7):1522.

8. Chen B, Wang KR, Li SK, et al. Monitoring Cotton Field with suspected Verticillium wilt using satellite Remote Sensing with TM Satellite Image as an Example. Acta Agronomica Sinica. 2012;38(1):129-39.

9. Chen H, Wang,JJ,Yang,B. Effects of Cd Stress on the Early Growth of Spinach and Rape. Journal of Shanxi Agricultural Sciences. 2016;44(9):1308-11.

10. Dąbrowski P, Baczewska AH, Pawluśkiewicz B. Prompt chlorophyll a fluorescence as a rapid tool for diagnostic changes in PSIl structure inhibited by salt stress in Perennial ryegrass. Journal of Photochemistry Photobiology B-biology. 2016;157:22-31.

11. Draper HH, Squires EJ, Mahmoodi H, et al. A Comparative evaluation of thiobarbituric acid methods for the determination of malondialdehyde in biological materials. Free Radic Biol Med. 1993;15(4):353-63.

12. Malaspina P, Giordani P, Pastorino G, et al. Interaction of sea salt and atmospheric pollution alters the OJIP fluorescence transient in the lichen Pseudevernia furfuracea (L.). Ecol Ind. 2015;50:251-7. 
13. Goltsev V, Zaharieva I, Chernev P, et al. Delayed fluorescence in a photosynthesis. Photosynth Research. 2009;101(3):21732.

14. Guo Y, Liu D, Zhao L. Effect of extracellular phytase prodduced by Bacillus subtilis T2 on salt tolerance of wheat seedlings. Chinese Journal of Applied Environmental Biology. 2009;15(1):39-43.

15. Habib-ur-Rehman A, Sarah A, Muhammad J, et al. Influence of sub-lethal crude oil concentration on growth, water relations and photosynthetic capacity of maize (Zea mays L.)plants. Environ Sci Pollut Res. 2016;23(18):18320-31.

16. Han YY, Fan SX, Zhang Q, et al. Effect of heat stress on the MDA, proline and soluble sugar content in leaf lettuce seedlings. Agricultural sciences. 2013;04(5):112-5.

17. Idriss EE, Borriss R. Extracellular phytase activity of Bacillus amyloliquefaciens FZB45 contributes to its plant-growthpromoting effect. Microbiology. 2002;148(7):2097-109.

18. Jermyn MA. Increasing the sensitivity of the anthrone method for carbohydrate. Anal Biochem. 1975;68(1):332-5.

19. Lebkuecher JG, Haldeman KA, Harris CE, et al. Development of photosystem II activity duringirradiance of etiolated Helianthus seedlings. Am J Bot. 1999;86(8):1087-92.

20. Li FM, Song QH, Liu HS, et al. Effects of pre-sowing irrigation and phosphorus application on water use and yield of spring wheat under semi-arid conditions. Agric Water Manag. 2002;49(3):173-83.

21. Li PM, Gao HY, Reto JS. Application of the fast chlorophyll fluorescence induction dynamics analysis in photosynthesis study. Journal of Plant Physiology Molecular Biology. 2005;31(6):559-66.

22. Litchtenthaler HK, Wellburn AR. Determinations of total carotenoids and chlorophylls a and $b$ of leaf extracts in different solvents. Biochem Soc Trans. 1983;11(5):591-2.

23. Liu SN, Tang WZ, Yang F, et al., 2016,Influence of biochar application on potassium-solubilising Bacillus mucilaginosus as potential biofertilizer. Preparative Biochemistry \& Biotechnology 1, 32-37.

24. Long J, He XZ, Li KZ, et al. Effects of nitrate stress on the antioxidant enzyme activities and sterol content in two spinach varieties with different resistance. Life Science Research. 2013;17(6):493-8.

25. Manjurul Haque,Md., Ilias,GNM, Molla AH. Impact of Trichodermaenriched biofertilizer on the growth and yield of mustard (Brassica rapa L.) and tomato (Solanum lycopersicon Mill.). A Scientific Journal of Krishi Foundation. 2012;10(2):10919.

26. Oukarroum A, Gharous ME, Goltsev V, et al. Delayed fluorescence emission as a probe for the response of photosynthetic organisms to high temperature exposure: a comparative study. J Lumin. 2016;180:321-7.

27. Oukarroum A, Madidi SDE, Schansker G. Probing the responses of barley cultivars (Hordeum vulgare L.) by chlorophyll a fluorescence OLKJIP under drought stress and re-watering. Environ Exp Bot. 2007;60(3):438-46.

28. Paunov M, Koleva L, Vassilev A. Effects of different metals on photosynthesis: cadmium and zinc affect chlorophyll fluorescence in durum wheat. Int J Mol Sci. 2018;19(3):787.

29. Pliego C, Ramos C. Screening for candidate bacterial biocontrol agents against soilborne fungal plant pathogens. Plant Soil. 2010;340(1):505-20.

30. Pooja M, Anjana J, Sonal M, et al. Chlorophyll a fluorescence study revealing effects of high salt stress on Photosystem II in wheat leaves. Plant Physiol Biochem. 2010;48:16-20.

31. Sami AA, Salwa MA. Application of trichoderma Harzianum T22 as a biofertilizer poteneial in maize growth. J Plant Nutr. 2014;37(1):30-49.

32. Shen BY, Yu B, Wang W, et al. Study on the application of humic ammonia,organic fertilizer,microbial fertilizer to eliminate continuous cropping obstacles of potato in the arid regions of Gansu. Soil\&Fertilizer Sciences in China. 2011;2:68-70.

33. Spoustova P, Synkova H, Valcke R, et al. Chlorophyll a fluorescence as a tool for a study of the Potato virus $Y$ effects on photosynthesis of nontransgenic and transgenic Pssuipt tobacco. Photosynthetica. 2013;51(2):191-201.

34. Strasser RJ, Tsimilli-Michael M, Qiang S, ey al. Simultaneous in vivo recording of prompt and delayed fluorescence and 820-nm reflection changes during drying and after rehydration of the resurrection plant Haberlea rhodopensis. Biochem 
Biophys Acta. 2010;1797:1313-26.

35. Strasser RJ, Tsimilli-Michael M, Srivastava A. 2004. Analysis of the chlorophyll a fluorescence transient. In: Papageorgiou, G.C., Govindjee, editors, Chlorophyll Fluorescence: a Signature of Photosynthesis. Kluwer Academic Publishers Press, Netherlands 321-362.

36. Tang YP, Sun X, Wen T, et al. Implications of terminal oxidase function in regulation of salicylic acid on soybean seedling photosynthetic performance under water stress. Plant Physiol Bioch. 2017;112:19-28.

37. Tomar RS, Jajoo A. A quick investigation of the detrimental effectsof environmental pollutant polycyclic aromatic hydrocarbon fluo-ranthene on the photosynthetic efficiency of wheat (Triticum aestivum). Ecotoxicology. 2013;22:1313-8.

38. Tung J, Goodwin PH, Hsiang T. Chlorophyll fluorescence for quantification of fungal foliar infection and assessment of the effectiveness of an induced systemic resistance activator. Eur J Plant Pathol. 2013;136(2):301.

39. Tsimilli-Michael M, Strasser R, 2013, Biophysical phenomics: evalua-tion of the impact of mycorrhization with Piriformospora indica. In:V arma A, Kost G, Oelmüller R, editors Piriformospora indica. SoilBiology. Springer, Berlin Heidelberg 173-190.

40. Wang JW, Zhao JJ, Li GL. Effects of new compound microbial fertilizer on physiological indexes of winter wheat. Journal of Southern Agriculture. 2018;49(10):1953-8.

41. Yan DY, He XY, Li YG. Effect of compound microbial fertilizer on the production of brassica chinensis. Journal of Anhui Agri. 2017;45(14):33-4.

42. Yiotis $C$, Manetas Y. Sinks for photosynthetic electron flow in green petioles and pedicels of Zantedeschia aethiopica: evidence for innately high photorespiration and cyclic electron flow rates. Planta. 2010;232:523-31.

43. Zhao Y, Zhang XB, Guo W. Physiological and biochemical characteristics and capacities of potassium-releasing of Bacillus mucilaginosus screened from different soils. Ecology Environmental Sciences. 2009;6:2283-6.

\section{Figures}
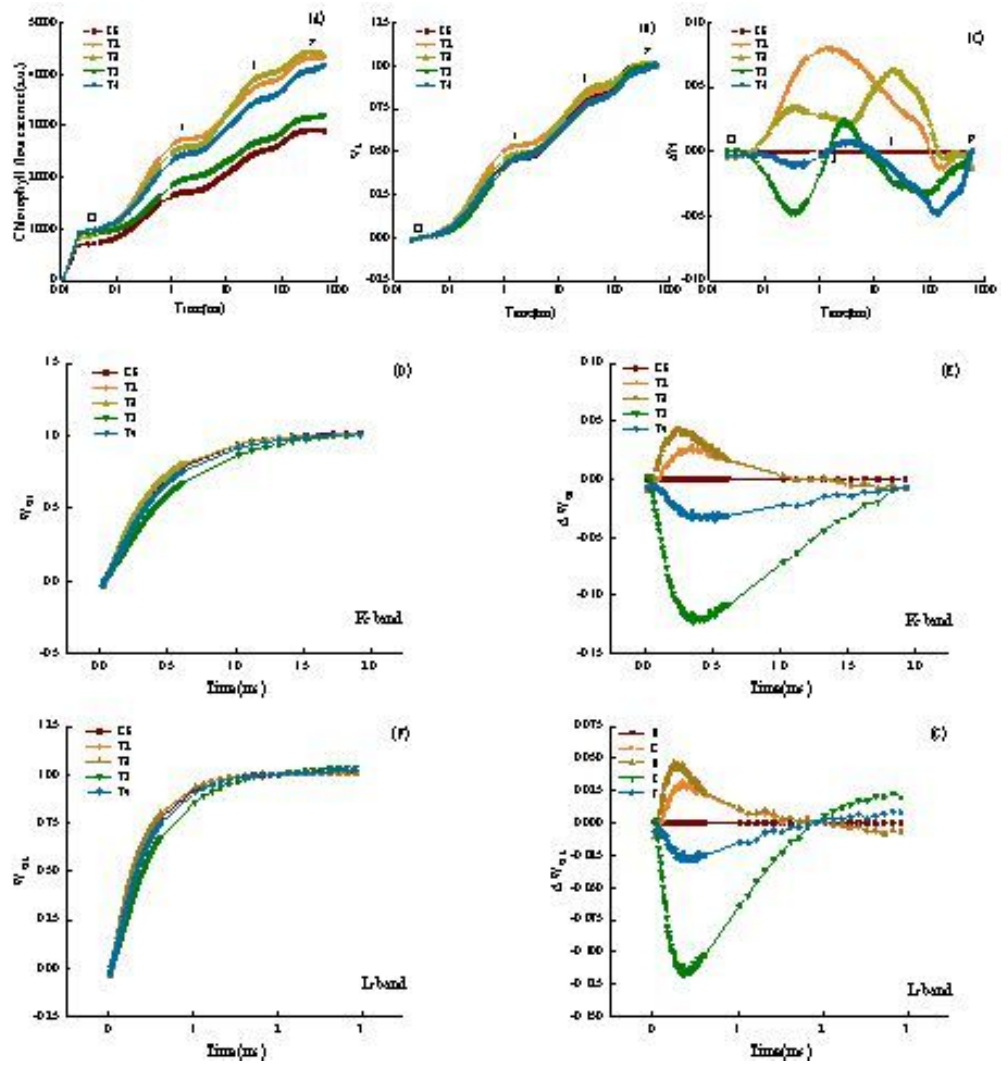

Figure 1 
Shape change of fluorescence transient curve measured through then addition of microbial fertilizer in the five different treatments. Each curve represents the average of three independent measurements.

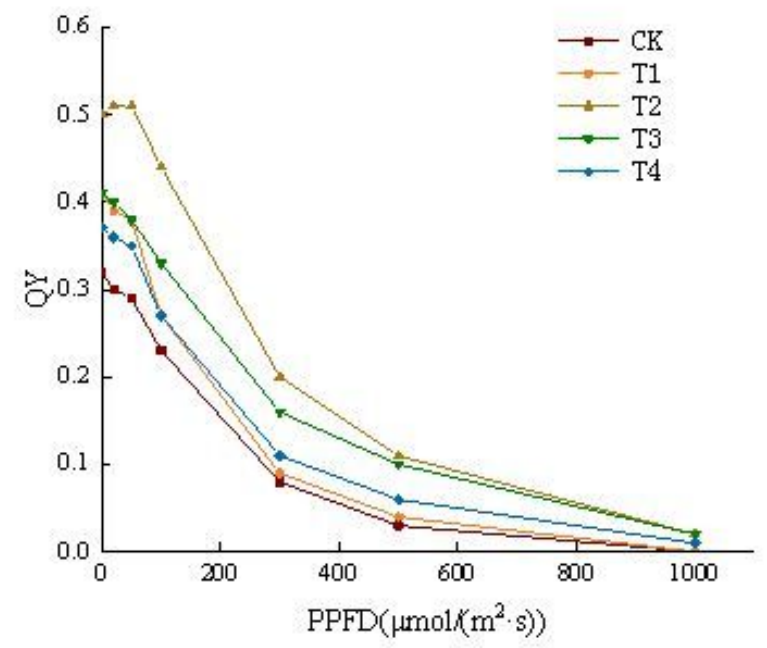

\section{Figure 2}

Light curve (LC) of quantum yield (QY) under the five different treatments. Data are the means of three experiments $( \pm S D)$. 